WORKING PAPER $\cdot$ NO. 2020-163

\title{
Effects of Welfare Reform on Parenting
}

Nancy Reichman, Hope Corman, Dhaval M. Dave, Ariel Kalil, and Ofira Schwartz-Soicher NOVEMBER 2020

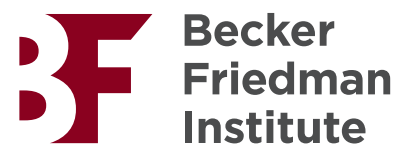




\section{EFFECTS OF WELFARE REFORM ON PARENTING}

Nancy Reichman

Hope Corman

Dhaval M. Dave

Ariel Kalil

Ofira Schwartz-Soicher

This work was supported by the Eunice Kennedy Shriver National Institute of Child Health and Human Development of the National Institutes of Health (award R01HD086223); the National Center for Advancing Translational Sciences, a component of the National Institutes of Health under award number UL1TR003017; the U.S. Department of Health and Human Services/Health Resources and Service Administration under award number U3DMD32755; and the Robert Wood Johnson Foundation through its support of the Child Health Institute of New Jersey (Grant 74260). The content is solely the responsibility of the authors and does not necessarily represent the official views of the Eunice Kennedy Shriver National Institute of Child Health \& Human Development, National Institutes of Health, or the Robert Wood Johnson Foundation. The authors are grateful to Abeeda Razack for excellent research assistance.

(C) 2020 by Nancy Reichman, Hope Corman, Dhaval M. Dave, Ariel Kalil, and Ofira SchwartzSoicher. All rights reserved. Short sections of text, not to exceed two paragraphs, may be quoted without explicit permission provided that full credit, including $\odot$ notice, is given to the source. 
Effects of Welfare Reform on Parenting

Nancy Reichman, Hope Corman, Dhaval M. Dave, Ariel Kalil, and Ofira Schwartz-Soicher

November 2020

JEL No. I3,J13

\begin{abstract}
This study investigated the effects of welfare reform in the 1990s, which represented a major policy shift that substantially and permanently retracted cash assistance to poor mothers in the U.S., on parenting. Using data on women from the 1979 cohort of the National Longitudinal Survey of Youth linked with information on their 10- to 14-year-old children from the Child SelfAdministered and Self-Report surveys, we exploited variation in the implementation of welfare reform across states, over time, and across treatment and comparison groups to estimate the effects of welfare reform on parent-child activities and closeness of the mother-child relationship. We found that welfare reform had adverse effects on engagement in parent-child activities, children feeling close to their mothers, and mothers knowing their children's whereabouts, with the effects generally concentrated among boys. These findings have implications for children's development and contribute to a virtually non-existent literature on the effects of welfare reform on parenting and the small but growing economic literature on parenting. We found no evidence that the effects of welfare reform on parenting operated through the mother working more than full time, having multiple jobs, working in a service job, or having a non-standard work schedule.
\end{abstract}

Nancy Reichman

Rutgers University

Robert Wood Johnson Medical School

Department of Pediatrics

Child Health Institute of New Jersey

89 French St., Room 3272

New Brunswick, NJ 08903

reichmne@rutgers.edu

Hope Corman

Department of Economics

Rider University

2083 Lawrenceville Road

Lawrenceville, NJ 08648

and NBER

corman@rider.edu

Dhaval M. Dave

Bentley University

Department of Economics

175 Forest Street, AAC 195

Waltham, MA 02452-4705

and IZA

and also NBER

ddave@bentley.edu
Ariel Kalil

Harris School of Public Policy

University of Chicago

1155 E. 60th Street

Chicago, IL 60637

a-kalil@uchicago.edu

Ofira Schwartz-Soicher

Princeton University

Donald Stokes Library

Princeton, US 08544

oschwart@princeton.edu 
Welfare reform in the U.S., which was implemented in the 1990s and remains in effect today, was a large-scale policy shift that dramatically limited cash assistance for low-income families (typically female-headed households) by imposing work requirements, time limits on cash assistance, stricter sanctions for non-compliance with program rules, and other restrictions. The assumption was that labor force participation would break a culture of dependence (Katz, 2001), but there also were concerns that the reforms would contribute to existing hardships (Lichter \& Jayakody, 2002).

The reforms have had substantial impact. Average monthly family welfare caseloads in the U.S. declined by 78\% between 1994 to 2017 (ACF, 2018). Employment of low-skilled women increased by as much as $27 \%$ as a result of the reforms (Fang \& Keane, 2004; Ziliak, 2016). Welfare reform led to declines in women's substance use (Corman et al., 2013; Kaestner \& Tarlov, 2006) and crime (Corman et al., 2014) and increases in women's civic participation in the form of voting (Corman, Dave \& Reichman, 2017). Thus, for the behavioral outcomes investigated, welfare reform has had favorable effects on women. However, substantial proportions of unmarried mothers reported financial difficulties, material hardship, and poor health in the aftermath of welfare reform (Teitler et al., 2004), perhaps because many jobs that are available to poor unmarried mothers have irregular work schedules, non-standard hours, low employment security, and few benefits (Johnson, Kalil \& Dunifon, 2014).

Another assumption behind the reforms was that a work-focused regime would not only improve behaviors of mothers, but that it would also improve behaviors and outcomes of the next generation and disrupt an intergenerational transmission of dependence. Studies have found that welfare reform led to decreased high school dropout (Dave et al., 2012) and teen fertility (Lopoo \& Raissian, 2012), at least in part through its "minor mother" requirements that mothers under 18 participate in education or training activities and live with a parent or guardian. Studies of early experimental welfare reform programs in specific states found few 
conclusive effects on other behaviors of teens, who are at a critical stage in the life course for their human capital trajectories, but a very recent study found that the reforms led to a significant increase in delinquent behaviors (skipping school, damaging property, fighting, stealing, hurting others) of teenage boys as well as increases in substance use of teens, with larger effects for boys than girls (Dave et al., 2020). At least some of the effects appeared to operate through parental supervision.

To better understand how welfare reform has affected the next generation, it is necessary to investigate how the reforms affected family functioning, the home environment, and parent-child interactions (Chase Lansdale \& Pittman, 2002). Little research on this topic exists, and most of what is known comes from experimental welfare demonstration projects that took place in certain states before the enactment of national welfare reform in 1996 . The findings from the small existing literature suggest that transitions from welfare to work had relatively few effects on parental depression or the home environment (Morris et al., 2009). Paxson and Waldfogel (2003) found suggestive evidence that early reforms led to increased cases of child maltreatment but emphasized that their results were preliminary. Nonexperimental studies of welfare leavers exposed to the national reforms have suggested the possibility of adverse changes in parental monitoring and supervision (Gennetian et al., 2002; Johnson, Kalil \& Dunifon, 2014). We know of no studies of the full implementation of welfare reform that used methodologically rigorous research designs. Understanding these links is important because the quality of the home environment and the emotional support and learning opportunities that parents provide in that setting are key inputs into children's development and long-run success (Bjorklund \& Salvanes, 2015; Kalil, 2015; Doepke, Sorrenti \& Zilibotti, 2019).

This study addresses this important knowledge gap by estimating the effects of welfare reform in the U.S.- - a major policy shift that established the current cash assistance landscape in the country-on parenting. We focus on children in the pre-teen and early teenage years 
(ages 10-14), a stage that is considered an especially sensitive period in child development during which the biological and psychological transition from childhood to adolescence takes place (Morris et al., 2005). Developmentally effective and positive parent-child relationships remain paramount at this stage during which parents must successfully scaffold the child's transition to greater autonomy and self-management of relationships with peers and other adults, as well as the biological and emotional changes associated with pubertal development (Chase-Lansdale et al., 2003; Morris, Duncan \& Clark-Kauffman, 2005).

\section{Background}

Welfare reform in the United States

The Personal Responsibility and Work Opportunity Reconciliation Act (PRWORA) of 1996, often referred to as welfare reform, ended entitlement to welfare benefits under Aid to Families with Dependent Children (AFDC) and replaced AFDC with Temporary Assistance for Needy Families (TANF) block grants to states. Key features of the legislation were time limits on cash assistance and work requirements as a condition for receiving benefits. States were granted considerable latitude in establishing eligibility and program rules subject to the national guidelines under PRWORA that mandated work requirements and a 5-year lifetime limit on the receipt of cash assistance.

Although welfare reform is often dated to the PRWORA legislation, reforms started taking place in the early 1990s when the Clinton Administration expanded the use of "welfare waivers" to allow states to carry out experimental changes to their AFDC programs. Although not federally mandated, waivers were implemented in the majority of states by the time the federal PRWORA legislation was enacted in 1996. Many features of PRWORA, such as work requirements and time-limited welfare receipt, were integral parts of these earlier programs.

Major statewide waivers—defined in a 1997 report by the Council of Economic Advisors (CEA, 1997) as those that substantially altered the nature of AFDC with respect to work 
requirements and incentives, time limits, and family caps-were introduced in 29 states over a period of 53 months, and TANF was implemented in all states over a period of 17 months. Considering both waivers and TANF, states reformed their welfare programs over a period of 64 months, from October 1992 through January 1998.

\section{Conceptual framework}

Although employment was its centerpiece, the PRWORA legislation established a broad, restrictive, and permanent new regime that drastically and permanently altered families' resources and constraints, which in turn could affect home environments and parent-child interactions. According to human capital models in economics, which focus on parental investments in their children (with two basic forms of inputs-time and money), changes in resources and constraints under welfare reform would alter the costs and benefits of making investments in children and ultimately affect children's outcomes. Increased net income from work would be expected to lead to increased financial investments in children while increased time constraints would be expected to lead to decreased time investments. Income can be used to purchase household services that free up parents' or children's time or allow for more of the kinds of parent-child interaction that cost money, such as outings outside the home. Increased time constraints can lead to fewer hours spent supervising children, providing emotional support, or fostering children's involvement in learning activities (Aizer, 2004). Akee et al. (2010) found that a positive income shock led to increases in parental supervision (percent of time parents knew their child's whereabouts and activities) as well as their children's reports of positive interactions with their mothers. The income shock did not lead to changes in the parents' labor force participation, so the authors inferred that the effects operated through improved parenting quality.

Facets of parenting quality include warmth and responsiveness; control and discipline; modeling of attitudes, values, and behaviors; gatekeeping (friends and outside activities); and 
family routines and traditions (Chase-Lansdale \& Pittman, 2002). Few studies in the economics literature have directly studied parenting quality, and most of those focused on the effects of parenting quality on child outcomes. For example, Majumder (2016) found that children whose parents had uninvolved parenting styles completed fewer years of schooling, and Cobb-Clark, Salamanca \& Zhu (2019) found that respectful parenting (from parent reports of respect for child's views and opinions, youth reports that their mothers respect their views and opinions, and youth reports that their mothers' behavior toward them is friendly) led to improved educational outcomes and non-cognitive skills and less engagement in substance use and other risky or delinquent behaviors.

The family and environmental stress perspective, drawn from theoretical models in psychology and sociology (Elder, 1998; Elder, Nguyen \& Caspi, 1985), can be used to conceptualize psychological processes contributing to parental investment decisions. This perspective focuses on how experiences of material scarcity and economic hardship negatively affect parental psychological well-being and cognitive capacities, which in turn negatively affect parenting behavior and, ultimately, children's development. This process can also work in reverse, with material resources and economic security positively affecting parenting behaviors and children's outcomes. It is also possible that greater attachment to the labor market improves a mother's self-esteem or provides more structure, leading to more positive parent-child interaction (Reichman \& McLanahan, 2001). Parenting quality is commonly considered the central explanatory process in these models.

According to the stress model perspective, economic pressure faced by poor families coupled with other stressful life experiences is linked with parenting practices that are on average more punitive, harsh, inconsistent, and detached as well as less nurturing, stimulating, and responsive to children's needs. Such lower-quality parenting is likely to elevate children's stress responses, and ultimately harm children's development (Conger \& Donnellan, 2007; 
Gershoff, Aber \& Raver, 2003; Sanders \& Morawska, 2018). This perspective has been broadened by recent work in behavioral economics that argues that conditions of poverty and scarcity not only create psychological distress, but also deplete important cognitive resources, specifically attention processes and behavioral self-control (Mani, Mullainathan, Shafir \& Zhao, 2013; Spears, 2011).

Effects of welfare reform on parent-child interactions and relationships may differ by the child's gender. For example, family labor in economically disadvantaged households, which includes caring for younger siblings, household management, and domestic chores, most often falls upon girls, in part because of gendered expectations regarding girls' versus boys' roles in domestic work (Dodson \& Dickert, 2004). Time-use studies have confirmed that teenage girls devote more time to household tasks than boys (Gager, Cooney \& Call, 1999). If the constraints imposed by welfare reform lead to increases in the amount time girls spend on household tasks, mother-daughter relationships may be more affected than mother-son relationships by welfare reform. This change could allow mothers and daughters to bond in relation to household production activities while mothers focus less on the adolescent and pre-teen boys, but it could also create conflict between mothers and daughters. Gender-specific effects of welfare reform on parental investments and parent-child relationships are important to study given past research suggesting that boys are more sensitive than girls to changes in time and monetary investments during childhood (Autor et al., 2019; Bertrand \& Pan, 2013; Conti, Heckman \& Pinto, 2015; Fan, Fang \& Markussen, 2015; Kling, Ludwig \& Katz, 2005; Lei \& Lundberg, 2020; Weitoft et al., 2003).

\section{Data}

We use restricted data from the 1979 cohort of the National Longitudinal Survey of Youth (NLSY) linked with information on respondents' children from the Child Self-Administered (CS) and Self-Report surveys. The original nationally representative sample consisted of over 
12,000 youth who were ages 14 to 22 years in 1979. The longitudinal survey began in 1979 , was conducted annually until 1994, and has been conducted biannually since then. ${ }^{1}$ Our observation period starts in 1990, several years before the beginning of welfare reform implementation. We use 2006 as the endpoint in order to allow all states to have fully implemented welfare reform and to avoid conflating our results with the effects of the Great Recession that began in the last quarter of 2007. The self-administered CS survey follows the biological children of the women in the original NLSY sample. The CS includes questions about the child's interactions with parents. Starting in 1994, the NLSY implemented the Young Adult (YA) survey, which was administered to children aged 15 years and older, and only administered the CS (which had much more detailed data on child/parent interactions than the YA surveys) to children ages 10-14. The YA survey contains different questions aimed at older teens and young adults—questions that were not comparable to the earlier years. Therefore, we confined our analysis to children aged 10 to 14.

The NLSY79 allows us to have an observation period that envelops welfare reform; has large sample sizes overall; includes information on parenting behaviors and parent-child relationships as experienced by the children; and includes the mother's marital status and education, which are needed for our analyses. As far as we know, there is no better data set available for estimating the effects of welfare reform on parenting using rigorous econometric techniques.

\section{Measures}

\section{Outcomes}

The NLSY CS asks children the following four sets of questions about what types of activities they do with their parents and about the closeness of the mother-child relationship. Specifically, the questions appear below.

\footnotetext{
${ }^{1}$ More information about the NLSY79 and the self-administered CS can be found at: https://www.nlsinfo.org/content/cohorts/nlsy79
} 
Activities outside the home. The child was asked: "Within the last month, have you and your parent(s)..." 1. Gone to a movie together; 2. Gone out to dinner; 3. Gone shopping to get something for you-such as clothes, books, records, or games; 4. Gone on an outing together, like to a museum or sporting event; and 5. Gone to church or religious services together. Each answer was dichotomous.

Activities inside the home. The child was asked: "Within the last week, have you and your parent(s)..." 1. Done things together such as build or make things; 2 . Worked on schoolwork together; and 3. Played a game or sport. Again, each answer was dichotomous. Child is close to mother. The child was asked: 1 . If he/she thinks his/her mother spends enough, too much, or not enough time with him/her. We coded this as 1 if the child responded either enough or too much time. 2. If his/her mother misses events or activities that are important to him/her. Options were a lot, sometimes, or almost never. We coded this as 1 if the child said almost never. 3. How well child and mother share ideas or talk about things that really matter. Options were extremely well, quite well, fairly well, or not very well. We coded this as 1 if the child reported quite or extremely well. 4. How close he/she feels to his/her mother. Options were extremely close, quite close, fairly close, or not very close. We coded this as 1 if the child reported quite or extremely close.

Mother knows child's whereabouts. The child was asked how often his/her mother knows who he/she is with when he/she is not at home. Options were often, sometimes, hardly ever. We coded this as 1 if the child answered often.

Welfare Reform

Following the convention in the welfare reform literature (Blank, 2002), we exploit differences in the timing of both AFDC waivers and TANF implementation across states. For waivers, we consider whether, in a given year and month, a given state had a statewide AFDC waiver in place that substantially altered the nature of AFDC with regard to time limits, work 
requirements, earnings disregards, sanctions, and/or family caps, based on the CEA classification (CEA 1997). For TANF, we consider whether, in a given year and month, the state had implemented TANF post-PRWORA. In most specifications, we include a single indicator for any welfare reform (AFDC waiver or TANF). In supplementary models, we use separate indicators for AFDC and TANF.

We matched the timing of each phase of welfare reform to the teens' records in the NLSY based on maternal state of residence and year and month of interview. A teen is considered exposed to welfare reform if the mother resided in a state in which welfare reform was implemented and had been in effect for at least 12 months-i.e., welfare reform was implemented in that state at least 12 months prior to the month of interview. The one-year lag allows for a lag between maternal exposure to welfare reform, maternal responses to welfare reform, and children's responses.

\section{Covariates}

Individual-level covariates in all analyses include the child's age (years), grade in school, and race/ethnicity (white, black, or other, with the last category including Hispanics). Mother's characteristics include education and marital status. State/year covariates include unemployment rate, poverty rate, personal income per capita, Earned Income Tax Credit (EITC) rate, refundable EITC, minimum wage, number of Medicaid beneficiaries, numbers of National School Breakfast and Lunch Program beneficiaries, and population.

\section{Methods}

Our analyses are based on a quasi-experimental difference-in-difference-in-differences (DDD) design that exploits variation in the timing of welfare reform implementation across states in conjunction with comparisons across treatment and comparison groups. This approach is standard in the economics literature on evaluating the effects of welfare reform. The following reduced-form baseline DDD specification directly relates changes in parenting variables to the 
child's exposure to welfare reform, for the target group relative to a comparison group:

$$
P_{\text {imst }}=\alpha+\Pi_{1}\left(\text { Welfare }_{\mathrm{st}-12} \text { * } \text { Target }_{\mathrm{mst}}\right)+\Pi_{2} \text { Welfare }_{\mathrm{st}-12}+X_{\text {imst }} \beta+V_{\mathrm{mst}} \lambda
$$

$+Z_{\text {st }} \beta+$ State $_{\mathrm{s}} \Omega+$ Time $_{\mathrm{t}} \Psi+\varepsilon_{\text {imst }}$

A given parenting indicator $(P)$, for the $i^{\text {th }}$ child born to mother $m$ residing in state $s$ and observed at time $t$, is a function of welfare reform (Welfare), measured here by an indicator for whether a given state had in place a major AFDC waiver (prior to enacting TANF) or had implemented TANF for at least 12 months. As indicated earlier, we build in the 12-month lag

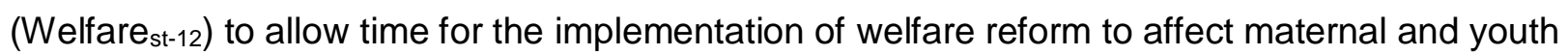
behaviors. We control for vectors of child characteristics $(X)$ and maternal characteristics $(V)$. Models are estimated separately by the child's gender because, as discussed earlier, there are many reasons to expect that boys and girls would respond differently to the policy shift. We estimate all models using Ordinary Least Squares (linear probability models) and report standard errors that are adjusted for arbitrary correlation in the error term $(\varepsilon)$ across and within individuals in a given state, and hence clustered at the state level.

To account for potentially confounding policy shifts, we include a rich set of time-varying state factors $(Z)$, detailed earlier and in table notes. The vector $Z$ also includes a set of lagged measures of the state's economic conditions (one-, two-, and three-year lags of the state's poverty rate, unemployment rate, and per capital personal income) and welfare caseload (one-, two-, and three-year lags of the state's AFDC or TANF caseload). These controls address the potential endogeneity of the timing of welfare reform, to the extent that early adoption of welfare reform may be driven by the state's economy and trends in welfare caseloads. Models further include State and Time (month/year of interview) fixed effects, which control for time-invariant state heterogeneity, national trends, and seasonal variations in youth outcomes.

The population of interest is children born to all women at risk of relying on public assistance, not just children born to current or former welfare recipients. Traditionally, the 
welfare caseload has consisted primarily of low-educated unmarried mothers (Bitler \& Hoynes, 2010). This at-risk population is the target group of women for whom welfare policy would be expected to have the largest effects on employment, income, and other household conditions and potentially the largest behavioral effects, if any. While we control for a large set of timevarying state-level factors, the possibility of omitted variables remains. The DDD framework addresses this issue by considering a comparison group - individuals similar in many ways to the target group but unlikely to participate in public assistance programs and therefore unlikely to be affected by welfare reform. In the above specification, Target represents a dichotomous indicator equal to 1 if the child is in the target group (has a low-educated unmarried mother and is thus at risk of being on welfare) and zero if in the child is in the comparison group (has a mother who is not at risk of being on welfare). Following the empirical welfare reform literature (e.g., Dave et al., 2020), our primary comparison group consists of married mothers with a high school education or less (comparison group A) - a group that has very low rates of welfare participation by virtue of generally being ineligible, and thus should minimally impacted by shifts in welfare policies. ${ }^{2}$ We also assess robustness to an alternate comparison group, consisting of unmarried mothers with more than a high school education, which has also been employed in the literature. The parameter of interest is $\Pi_{1}$, the coefficient of the interaction term between the policy measure (Welfare) and the Target group indicator, which represents the reduced-form effects of exposure to welfare reform on parenting outcomes operating through any and all reinforcing and/or offsetting channels.

In these models, the error terms $(\varepsilon)$ for a given individual $i$ are likely to be correlated

\footnotetext{
${ }^{2}$ Data from the American Community Surveys (2001-2002) indicate that only about 2\% of low-educated married mothers reported any income from public assistance; in comparison, participation in cash public assistance was almost seven-fold higher (about 14\%) among low-educated unmarried mothers. The participation rate is higher (17\%) for low-educated mothers with young children (children under age 5). It should be noted that this prevalence (14-17\%) likely underestimates this group's engagement with the welfare system, since it does not capture everparticipation, that is women who have relied on welfare in the past (but may have used up their lifetime benefits or are no longer on welfare) or current non-participants who may yet rely on cash assistance in the future.
} 
across the various outcomes since behaviors tend to be clustered together within individuals. Accounting for this cross-equation correlation across outcomes can increase statistical power and improve the efficiency of estimates. In alternative specifications, we transform the outcome variables into a consistent scale, standard normal deviates [(Y - mean)/standard deviation $]$ and estimate the effects of welfare reform on youth behaviors using a seemingly unrelated regression (SUR) framework, allowing us to test joint hypotheses across equations. These estimates are evaluated as changes in standard normal deviations of the dependent variable, and we test whether the average estimate across models is statistically different from zero. This approach has the added advantages of bypassing issues related to multiple comparisons and testing and yielding a consistently defined average magnitude across outcomes, making it straightforward to compare effects across gender and model specification.

We estimate models for each individual outcome, as well as SURs for each of the four categories of outcomes (does activities outside the home with parent(s), does activities in the home with parent(s), is close to mother, and mother knows child's whereabouts). Finally, we estimate a SUR model that includes all 13 parenting outcomes.

The validity of our identification strategy, which exploits variation in the timing of implementation of welfare reform across states (difference-in-differences) in conjunction with a comparison of "treated" and "control" groups (third "difference"), depends on similar trends in outcomes for target and comparison groups before the implementation of welfare reform ("parallel trends" assumption). We assess parallel trends by expanding the standard DDD model specified in Equation 1 and separating the DDD effect into flexible pre-policy lead effects and the average post-policy response. We also implement a placebo check by estimating our main 
models for a sample of higher-educated married mothers who should not be impacted by welfare policies given their extremely low rates of welfare participation. ${ }^{3}$

\section{Results}

Table 1 shows the pre-welfare reform means (before 1993) for the 13 individual outcome variables for the target and comparison groups, by child gender. The differences between the target group and each of the two comparison groups are rather modest. Comparing boys and girls, the biggest differences are that girls are more likely than boys to share their whereabouts with their mothers.

In Table 2, we present DDD estimates of the effects of welfare reform on the various groups of parenting measures from a SUR framework, using our primary comparison group of low-educated married mothers ("Comparison Group A"). The estimates can be interpreted as the average standard deviation welfare-reform associated difference in the relevant outcomes between the target and comparison groups. For boys in the target group compared with those in the control group, welfare reform was associated with a decrease of about 0.08 standard deviations in activities together outside the home, although this result is not precisely estimated ( $p$-value is about 0.101). For girls, the corresponding estimate is quite small, positive, and statistically insignificant. For both boys and girls in the target group, welfare reform was associated with decreases in activities together in the home, by about $0.07-0.08$ standard deviations. There are striking differences by gender on the effects of welfare reform on closeness to mothers; welfare reform was associated with about a 0.09 standard deviation decrease for boys, while the corresponding effect size was negligible and insignificant for girls. Similarly, welfare reform was negatively (and somewhat significantly) associated with mothers

\footnotetext{
${ }^{3}$ Data from the 2001-2002 American Community Surveys indicate that $0.4 \%$ of educated (some college or above) mothers with minor children in the household reported receiving cash public assistance.
} 
knowing their children's whereabouts for boys, while the corresponding estimate was very small, positive, and statistically insignificant for girls.

The last set of models in Table 2 estimates the composite effect of welfare reform for all 13 parenting measures via SUR. Overall, welfare reform had a significant negative association with parenting for boys (about 0.09 standard deviations) and an insignificant association for girls. These estimates suggest that welfare reform compromised the quality and quantity of parenting inputs for boys but had little effect on the parenting of girls. While the gender differences in the effects of welfare reform on parenting inputs are intriguing, the estimated difference is only on the margin of statistical significance ( $p$-value $=0.103$ for the null of no gender difference).

Table 3 replicates the analyses in Table 2 utilizing unmarried mothers with at least a high school education as the comparison group. The DDD estimates and gender patterns are robust to this alternative specification. We continue to find a marginally significant welfare reform-associated decline in parental inputs for boys, on the order of about 0.1 standard deviation and smaller and insignificant effects of welfare reform on parenting outcomes for girls.

Appendix Tables 1-3 present disaggregated results for each of the 13 parenting measures; Appendix Table 1 presents results for activities outside the home, Appendix Table 2 presents results for activities inside and whereabouts, and Appendix Table 3 presents results for closeness to mother. These estimates are generally imprecise compared with those from the SUR models; indeed, one of the advantages of the SUR framework is that accounting for the correlation in the cross-equation error terms improves statistical power and precision (Dave et al., 2020). However, the estimates and patterns are largely similar to those from the SUR models in that they suggest a worsening of parent/adolescent relationships, particularly for boys, as a result of welfare reform. 
In Table 4, we present estimates corresponding to those in Table 2 but excluding all state-level covariates (Panel A) and excluding just the lagged state covariates, which had been included to address potential policy endogeneity (Panel B). ${ }^{4}$ To facilitate comparison, we also reproduce the estimates from the more saturated specification (from Table 2), which includes all of the state-level policy and economic variables as well as the lagged state covariates (Panel C) and find that the estimates are robust to the more parsimonious specifications. The fact that the treatment effects are insensitive to excluding the state-level controls instills some degree of confidence in the quality of the natural experiment-i.e., that the welfare reform effects we are capturing are not confounded by other observed state-level economic and policy factors.

In Table 5, we present estimates from an expanded formulation of Equation 1 that parses out the pre-reform trends from the post-reform treatment effects. Specifically, we define windows of time with respect to welfare reform implementation (month/year of implementation in each state) capturing pre-policy leads (5+ or $4+, 3$, and 2 years prior to implementation), the year of implementation, and periods more than one year after implementation (our main postpolicy window, allowing for a 1-year lag). These results highlight four main points, all of which are jointly validating. First, there is little systematic evidence of differential pre-policy trends for boys or girls; the lead pre-policy effects are individually and jointly insignificant. Second, allowing for potential trend differentials across the target and comparison groups does not alter our conclusions. The main post-policy estimates remain largely unchanged when we control for the lead policy effects (comparing estimates in Columns 2 and 3 with the baseline estimates in Column 1 for boys and comparing estimates in Columns 5 and 6 with the baseline estimates in Column 4 for girls). Third, significant effects on parental inputs become apparent, for boys, only after the implementation or welfare reform - not before. Finally, we do not find any substantial or significant effects of the welfare reform the first year after implementation. It would not be

\footnotetext{
${ }^{4}$ Results using Comparison Group B are similar (available upon request).
} 
credible to expect an immediate effect of the reforms on parental inputs given expected lags between exposure to welfare reform, maternal responses, and changes in children's assessments of relationships.

Table 6 presents estimated effects of welfare reform on parenting outcomes among children of married mothers with some college education or more, as a placebo check. These are DD estimates since no comparison group is utilized. Across all sets of parenting outcomes, the standardized effects of welfare reform are statistically insignificant, small, and close to zero. These findings are validating, as welfare policy should have no impact on this demographic group.

Finally, we explored the potential mediating roles of the mother working outside of the home more than 40 hours per week, working at 2 or more jobs, working at a service job, and having a non-standard work schedule on the effects of welfare reform on parenting outcomes and found no compelling evidence that the effects operated through those channels (not shown).

\section{Conclusion}

Welfare reform, which took place in the 1990s, represented a major policy shift that substantially and permanently retracted cash assistance to poor mothers in the U.S. The premise was that working would break a culture of dependence by increasing self-sufficiency in the short and long term and across generations. Although previous research has documented many favorable effects of welfare reform for mothers, including increased employment, decreased substance use and crime, and increased civic participation, the effects on human capital-related behaviors of the next generation appear to be less uniformly favorable with some differences by gender. The studies finding that welfare reform led to decreased high school dropout and teen fertility focused almost exclusively on girls. A recent study of adolescent delinquent behaviors (which are precursors to crime) and use of cigarettes, alcohol, marijuana, 
and hard drugs (all of which are illegal behaviors for minors) found that the welfare reform led to increases in delinquent behaviors of boys as well as increases in substance use of both boys and girls, with larger effects for boys (Dave et al., 2020). Although the authors were limited in their ability to explore potential mediating factors, they found some evidence that the effects operated at least partially through maternal supervision.

In this study, we investigated the effects of welfare reform on several dimensions of parenting and found that welfare reform led to decreases in parent-child activities, children feeling close to their mothers, and mothers knowing their children's whereabouts, with the effects generally concentrated among boys. These findings have implications for children's development and contribute to the virtually non-existent literature on the effects of welfare reform on parenting and the small but growing economic literature on parenting. The findings also suggest that parent involvement and parent-child closeness could underlie the findings of Dave et al. (2020) that welfare reform led to increases in delinquent behaviors of boys and increases of substance use among teens, particularly of boys. However, since the typical effect size for boys was only about .10 standard deviation, it is unlikely that these dimensions of parenting would explain a substantial proportion of the effects in that study. It is possible that interactions or experiences at school or other environments in which children interact play more prominent roles in shaping adolescent delinquent behaviors and substance use than parent involvement and parent-child closeness.

We found no evidence that the effects of welfare reform on parenting operated through the mother working more than full time, having multiple jobs, working in a service job, or having a non-standard work schedule, but were not able to explore other relevant maternal working conditions such as low employment security and lack of benefits. We infer that the effects operated through maternal stress, which could have been related to work conditions but also could have resulted from confronting a permanently reduced safety net. As such, the findings 
from this study contribute to a small but growing literature in economics suggesting that boys are more sensitive than girls to economic disadvantage and stressful environmental conditions (Autor et al. 2020). 


\section{References}

Administration for Children and Families, U.S. Department of Health and Human Services. 2018. Compiled by authors from annual caseload reports available at: https://www.acf.hhs.gov/ofa/programs/tanf/data-reports

Aizer, A. 2004. Home Alone: Supervision After School and Child Behavior. Journal of Public Economics, 88 (9-10), 1835-1848.

Akee, R., Copeland, W.E., Keeler, G., Angold, A., \& Costello, E.J. 2010. Parents' Incomes and Children's Outcomes: A Quasi-Experiment Using Transfer Payments from Casino Profits. American Economic Journal: Applied Economics, 2 (1), 86-115.

Autor, D., Figlio, D., Krzysztof, K, Roth, J., Wasserman, M. 2019. Family Disadvantage and the Gender Gap in Behavioral and Educational Outcomes. American Economic Journal: Applied Economics, 11(3), 338-381.

Autor, D.H., Figlio, D., Karbownik, K., Roth, J., Wasserman, M. 2020. Males at the Tails: How Socioeconomic Status Shapes the Gender Gap. NBER Working Paper 27196, National Bureau of Economic Research, Cambridge, MA.

Bertrand, M., Pan, J. 2013. The Trouble with Boys: Social Influences and the Gender Gap in Disruptive Behavior. American Economic Journal: Applied Economics, 5 (1), 32-64.

Bitler, M.P., Hoynes, H.W. 2010. The State of the Social Safety Net in the Post-Welfare Reform Era." Brookings Papers on Economic Activity 2, 71-127.

Bjorklund, A., Salvanes, K.G. 2011. Education and Family Background: Mechanisms and Policies. Handbook of Economics of Education 3, 201-247.

Blank, R.M. 2002. Evaluating Welfare Reform in the United States. NBER Working Paper 8983, National Bureau of Economic Research, Cambridge, MA.

Chase-Lansdale, P L., Moffitt, R.A., Lohman, B.J., Cherlin, A.J., Coley, R.L., Pittman, L.D., ... \& Votruba-Drzal, E. 2003. Mothers' Transitions from Welfare to Work and the Well-being of Preschoolers and Adolescents. Science, 299(5612), 1548-1552.

Council of Economic Advisors, 1997. Technical Report: Explaining the Decline in Welfare Receipt. Washington, D.C.: U.S. Government Printing Office.

Chase Lansdale, P., Pittman, L. 2002. Welfare Reform and Parenting: Reasonable Expectations. The Future of Children, 12(1), 167-185.

Cobb-Clark, D. A., Salamanca, N., \& Zhu, A. 2019. Parenting Style as an Investment in Human Development. Journal of Population Economics, 32(4), 1315-1352.

Conger, R.D., \& Donnellan, M.B. 2007. An Interactionist Perspective on the Socioeconomic Context of Human Development. Annu. Rev. Psychol., 58, 175-199.

Conti, G., Heckman, J.J., \& Pinto, R. 2016. The Effects of Two Influential Early Childhood Interventions on Health and Healthy Behaviors. Economic Journal, 126 (596), F28-F65.

Corman, H., Dave, D.M., Reichman, N.E. 2017. Effects of Welfare Reform on Women's Voting Participation. Economic Inquiry, 55 (3), 1430-1451.

Corman, H., Dave, D.M., Reichman, N.E. 2014. Effects of Welfare Reform on Women's Crime. International Review of Law and Economics, 40, 1-14.

Corman, H., Dave, D.M., Reichman, N.E., Das, D. 2013. Effects of Welfare Reform on Illicit Drug Use of Adult Women. Economic Inquiry, 51, 653-674.

Dave, D., Corman, H., Kalil, A., Schwartz-Soicher, O., Reichman, N. (2020). Intergenerational Effects of Welfare Reform: Adolescent Delinquent and Risky Behaviors. Economic Inquiry. Available online ahead of print: https://onlinelibrary.wiley.com/doi/full/10.1111/ecin.12931

Dave, D.M., Reichman, N.E., \& Corman, H. 2012. Effects of Welfare Reform on Education Acquisition on Young Adult Women. Journal of Labor Research, 33(2), 251-82.

Dodson, L., \& Dickert, J. 2004. Girls' Family Labor in Low-income Households: A Decade of Qualitative Research. Journal of Marriage and Family, 66(2), 318-332 
Doepke, M., Sorrenti, G., Zilibotti, F. 2019. The Economics of Parenting. Annual Review of Economics, 11(1), 55-84.

Elder, G.H., Jr. 1998. The Life Course as Developmental Theory. Child Development, 69(1), 112.

Elder, G.H., Jr., Van Nguyen, T., \& Caspi, A. 1985. Linking Family Hardship to Children's Lives. Child Development, 56, 361-375.

Fan, X., Fang, H., \& Markussen, S. 2015. Mothers' Employment and Children's Educational Gender Gap. NBER Working Paper 21183, National Bureau of Economic Research, Cambridge, MA.

Fang, H., Keane, M. 2004. Assessing the Impact of Welfare Reform on Single Mothers. Brookings Papers on Economic Activity. The Brookings Institution: Washington DC. Accessed on April 23, 2017 at: https://www.brookings.edu/bpea-articles/assessing-theimpact-of-welfare-reform-on-single-mothers/

Gager, C.T., Cooney, T.M. Call, K.T. 1999. The Effects of Family Characteristics and Time Use on Teenagers' Household Labor. Journal of Marriage and the Family, 11 (1), 982-994.

Gennetian, L.A., Duncan, G.J., Knox, V.W., Vargas, W.G., Clark-Kauffman, E., \& London, A.S. 2002. How Welfare and Work Policies for Parents Affect Adolescents: A Synthesis of Research. Accessed on April 23, 2017 at: http://www.mdrc.org/publication/how-welfareand-work-policies-parents-affect-adolescents

Gershoff, E.T., Aber, J.L., \& Raver, C.C. 2003. Child Poverty in the US: An Evidence-based Framework for Programs and Policies. In Promoting Positive Child, Adolescent, and Family Development: A Handbook of Program and Policy Innovations (pp. 81-136). Sage Publications: Thousand Oaks, CA.

Johnson, R C., Kalil, A., \& Dunifon, R.E. 2012. Employment Patterns of Less-skilled Workers: Links to Children's Behavior and Academic Progress. Demography, 49(2), 747-772.

Kaestner, R., Tarlov, E. 2006. Changes in the Welfare Caseload and the Health of LowEducated Mothers. Journal of Policy Analysis and Management, 25 (3), 623-643.

Kalil, A. 2015. Inequality Begins at Home: The Role of Parenting in the Diverging Destinies of Rich and Poor Children. Pp. 63-82 in P.R. Amato et al. (eds.), Families in an Era of Increasing Inequality. National Symposium on Family Issues 5. Switzerland: Springer International Publishing.

Katz, M.B. The Price of Citizenship: Redefining the American Welfare State. New York, NY: Metropolitan Books, Henry Holt \& Co., 2001.

Kling, J.R., Ludwig, J., Katz, L.F. 2005. Neighborhood Effects on Crime for Female and Male Youth: Evidence from a Randomized Housing Voucher Experiment. The Quarterly Journal of Economics, 120 (1), 87-130.

Lei, Z., Lundberg, S. 2020.Vulnerable Boys: Short-term and Long-term Gender Differences in the Impacts of Adolescent Disadvantage. Human Capital and Economic Opportunity Global Working Group working paper, University of Chicago. https://hceconomics.uchicago.edu/research/working-paper/vulnerable-boys-short-termand-long-term-gender-differences-impacts?fbclid=IwAR1nrbxpnGAn700LvzY7EPyfXsV0YkbDsra-QaAvJ69cc2iXD7WONYnKUc

Lichter, D.T., \& Jayakody, R. 2002. Welfare Reform: How Do We Measure Success" Annual Review of Sociology, 28, 117-41.

Lopoo, L.M, Raissian, K.M. 2012. Natalist Policies in the United States. Journal of Policy Analysis and Management, 31 (4), 905-46.

Majumder, M. A. 2016. The Impact of Parenting Style on Children's Educational Outcomes in the United States. Journal of Family and Economic Issues, 38(1), 89-98.

Mani, A., Mullainathan, S., Shafir, E., Zhao, J. 2013. Poverty Impedes Cognitive Function. Science 341, 976-980. 
Morris, P., Duncan, G.J., \& Clark-Kauffman, E. 2005. Child Well-being in an Era of Welfare Reform: The Sensitivity of Transitions in Development to Policy Change. Developmental Psychology, 41(6), 919.

Morris, P., Gennetian, L., Duncan, G., Huston, A. 2009. How Welfare Policies Affect Child and Adolescent School Performance: Investigating Pathways of Influence with Experimental Data. In Welfare Reform and its Long-Term Consequences for America's Poor, James P. Ziliak, ed, Cambridge, UK: Cambridge University Press, 255-289.

Paxson, C., Waldfogel, J. 2003. Welfare Reforms, Family Resources, and Child Maltreatment. Journal of Policy Analysis and Management, 22 (1), 85-113.

Reichman, N., McLanahan, S. 2001. Self-Sufficiency Programs and Parenting Interventions: Lessons from New Chance and the Teenage Parent Demonstration. Social Policy Report 15(2): 3-4 \& 6 \& 8-11.

Sanders, M.R., Morawska, A. 2018. Handbook of Parenting and Child Development Across the Lifespan. Springer International Publishing AG. Available at: https://link.springer.com/content/pdf/10.1007\%2F978-3-319-94598-9.pdf

Spears, D. 2011. Economic Decision-Making in Poverty Depletes Behavioral Control. The BE Journal of Economic Analysis \& Policy, 11(1).

Teitler, J., Reichman, N., Nepomnyaschy, L. 2004. Sources of Support, Child Care, and Hardship Among Unwed Mothers, 1999-2001. Social Service Review, 78(1), 125-148.

Weitoft, G.R., Hjern, A., Haglund, B., \& Rosén, M. (2003). Mortality, Severe Morbidity, and Injury in Children Living with Single Parents in Sweden: A Population-based Study. The Lancet, 361(9354), 289-295.

Ziliak, J.P. 2016. Temporary Assistance for Needy Families. Pp. 303-393 in Robert A. Moffitt, (ed.), Economics of Means-Tested Transfer Programs in the United States, Volume 1. University of Chicago Press. 
Table 1: Weighted Mean Parenting Outcomes, Target and Comparison Groups, NLSY, 1990-1992 Boys 10-14

Girls 10-14

\begin{tabular}{|c|c|c|c|c|c|c|}
\hline Outcomes & Target Group & Comparison $\mathrm{A}$ & Comparison B & Target Group & Comparison A & Comparison B \\
\hline \multicolumn{7}{|c|}{ Outside of home activities w/parent(s) past month } \\
\hline Movies & 0.4126 & 0.3098 & 0.5213 & 0.2881 & 0.2848 & 0.4526 \\
\hline Dinner & 0.5286 & 0.6437 & 0.5745 & 0.5182 & 0.6198 & 0.6316 \\
\hline Shopping for child & 0.8113 & 0.7895 & 0.7872 & 0.8285 & 0.8311 & 0.7684 \\
\hline Outings & 0.3026 & 0.3917 & 0.3978 & 0.2715 & 0.3411 & 0.2842 \\
\hline Church & 0.4569 & 0.5185 & 0.5543 & 0.4934 & 0.5075 & 0.4894 \\
\hline \multicolumn{7}{|c|}{ In home activities with parent(s) past week } \\
\hline Schoolwork & 0.5129 & 0.4228 & 0.5426 & 0.4903 & 0.4354 & 0.4000 \\
\hline Games & 0.4506 & 0.5494 & 0.4516 & 0.4230 & 0.3947 & 0.3789 \\
\hline Other activities & 0.4684 & 0.4418 & 0.5053 & 0.6117 & 0.5750 & 0.5158 \\
\hline \multicolumn{7}{|c|}{ Close to mother } \\
\hline $\begin{array}{l}\text { Mother spends enough } \\
\text { time with child }\end{array}$ & 0.6535 & 0.7128 & 0.6200 & 0.6813 & 0.6888 & 0.6719 \\
\hline $\begin{array}{l}\text { Child and mother } \\
\text { share ideas } \\
\text { quite/extremely well }\end{array}$ & 0.6881 & 0.6499 & 0.6800 & 0.7569 & 0.7378 & 0.6406 \\
\hline $\begin{array}{l}\text { Mother almost never } \\
\text { misses child's } \\
\text { important events }\end{array}$ & 0.3618 & 0.4679 & 0.4200 & 0.3626 & 0.5202 & 0.5079 \\
\hline $\begin{array}{l}\text { Child feels quite or } \\
\text { extremely close to } \\
\text { mother }\end{array}$ & 0.8458 & 0.8833 & 0.8800 & 0.8571 & 0.8103 & 0.7188 \\
\hline \multicolumn{7}{|c|}{ Mother knows child's whereabouts } \\
\hline & 0.7438 & 0.7646 & 0.7600 & 0.7923 & 0.8506 & 0.8281 \\
\hline
\end{tabular}

Notes: Figures are column proportions. Target Group includes children of mothers who are unmarried and have a high school education or less (group at risk for relying on welfare). Comparison Group A includes children of mothers who are married and have a high school education or less. Comparison Group B includes children of mothers who are unmarried and have more than a high school education. 
Table 2: Seemingly Unrelated Regressions: Estimated Effects of Welfare Reform on Parenting Outcomes - Comparison Group A

\begin{tabular}{|c|c|c|c|c|c|}
\hline & \multicolumn{5}{|c|}{ Boys 10-14 } \\
\hline & $\begin{array}{c}\text { Activities } \\
\text { outside home } \\
\text { together } \\
\text { (5 activities) }\end{array}$ & $\begin{array}{c}\text { Activities } \\
\text { inside home } \\
\text { together } \\
\text { (3 activities) }\end{array}$ & $\begin{array}{l}\text { Child feels } \\
\text { close to } \\
\text { mother } \\
\text { (4 measures) }\end{array}$ & $\begin{array}{c}\text { Mother knows } \\
\text { child's } \\
\text { whereabouts } \\
\text { (1 measure) }\end{array}$ & $\begin{array}{l}\text { Composite } \\
\text { (all } 13 \\
\text { measures) }\end{array}$ \\
\hline $\begin{array}{l}\text { Any } \\
\text { welfare } \\
\text { reform }\end{array}$ & $\begin{array}{c}-0.01684 \\
(0.04608) \\
{[0.715]}\end{array}$ & $\begin{array}{c}-0.00286 \\
(0.05531) \\
{[0.959]}\end{array}$ & $\begin{array}{c}0.04340 \\
(0.03408) \\
{[0.203]}\end{array}$ & $\begin{array}{c}0.03143 \\
(0.06085) \\
{[0.606]} \\
\end{array}$ & $\begin{array}{c}0.00863 \\
(0.02846) \\
{[0.762]} \\
\end{array}$ \\
\hline $\begin{array}{l}\text { Any } \\
\text { welfare } \\
\text { reform * } \\
\text { target }\end{array}$ & $\begin{array}{c}-0.07999 \\
(0.04879) \\
{[0.101]}\end{array}$ & $\begin{array}{c}-0.06814^{*} \\
(0.03913) \\
{[0.082]}\end{array}$ & $\begin{array}{c}-0.09310^{\star *} \\
(0.04589) \\
{[0.042]}\end{array}$ & $\begin{array}{c}-0.14497^{*} \\
(0.07727) \\
{[0.061]}\end{array}$ & $\begin{array}{c}-0.08629 * \star \star \\
(0.03117) \\
{[0.006]}\end{array}$ \\
\hline $\mathrm{N}$ & 3761 & 3741 & 3350 & 3351 & 4002 \\
\hline
\end{tabular}

\begin{tabular}{|c|c|c|c|c|c|}
\hline & \multicolumn{5}{|c|}{ Girls 10-14 } \\
\hline & $\begin{array}{c}\text { Activities } \\
\text { outside home } \\
\text { together } \\
\text { (5 activities) }\end{array}$ & $\begin{array}{c}\text { Activities } \\
\text { inside home } \\
\text { together } \\
\text { (3 activities) }\end{array}$ & $\begin{array}{l}\text { Child feels } \\
\text { close to } \\
\text { mother } \\
\text { (4 measures) }\end{array}$ & $\begin{array}{c}\text { Mother knows } \\
\text { child's } \\
\text { whereabouts } \\
(1 \text { measure })\end{array}$ & $\begin{array}{l}\text { Composite } \\
\text { (all } 13 \\
\text { measures) }\end{array}$ \\
\hline $\begin{array}{l}\text { Any } \\
\text { welfare } \\
\text { reform }\end{array}$ & $\begin{array}{c}0.01018 \\
0.03567 \\
{[0.775]}\end{array}$ & $\begin{array}{c}-0.06653 \\
(0.04458) \\
{[0.136]}\end{array}$ & $\begin{array}{c}0.10175^{\star} \\
0.05853 \\
{[0.082]}\end{array}$ & $\begin{array}{c}0.07397 \\
(0.06836) \\
{[0.279]}\end{array}$ & $\begin{array}{c}0.02556 \\
(0.03219) \\
{[0.427]}\end{array}$ \\
\hline $\begin{array}{l}\text { Any } \\
\text { welfare } \\
\text { reform * } \\
\text { target }\end{array}$ & $\begin{array}{c}0.00821 \\
(0.04236) \\
{[0.846]}\end{array}$ & $\begin{array}{c}-0.08324^{*} \\
(0.04739) \\
{[0.079]}\end{array}$ & $\begin{array}{c}-0.03413 \\
(0.06891) \\
{[0.620]}\end{array}$ & $\begin{array}{c}0.00802 \\
(0.07288) \\
{[0.912]}\end{array}$ & $\begin{array}{c}-0.02593 \\
0.03618 \\
{[0.473]}\end{array}$ \\
\hline $\mathrm{N}$ & 3639 & 3637 & 3243 & 3245 & 3843 \\
\hline $\begin{array}{l}\text { Gender } \\
\text { Difference } \\
\text { [p-value] }\end{array}$ & [0.106] & [0.758] & [0.395] & [0.151] & [0.103] \\
\hline $\begin{array}{l}\text { tes: Figures } \\
\text { interest are t } \\
\text { vel. Asterisks } \\
\text { ecifications ir } \\
\text { atus; annual s } \\
\text { edit (EITC) ra } \\
\text { id School Bre }\end{array}$ & $\begin{array}{l}\text { the followin } \\
\text { vel measur } \\
\text { undable EIT }\end{array}$ & $\begin{array}{l}\text { lows: } * \star \star p- \\
\text { tes: child's } \\
\text { aployment } r \\
\text { lum wage, }\end{array}$ & ling, & $\begin{array}{l}\text { and p-value } \\
\text { dard errors ar } \\
\text { ue } \leq 0.05 ;{ }^{*} 0 \\
\text { ity; the mother } \\
\text { ncome per car }\end{array}$ & $\begin{array}{l}\text { kets]. Estima } \\
\text { red at the sta } \\
\text { value } \leq 0.10 \text {. } \\
\text { ation and mar } \\
\text { ned Income } \\
\text { lal School Lur } \\
\text { Target grou } \\
\text { ed mothers v }\end{array}$ \\
\hline
\end{tabular}


Table 3: Seemingly Unrelated Regressions: Estimated Effects of Welfare Reform on Parenting Outcomes- Comparison Group B

\begin{tabular}{|c|c|c|c|c|c|}
\hline 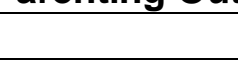 & \multicolumn{5}{|c|}{ Boys 10-14 } \\
\hline & $\begin{array}{c}\text { Activities } \\
\text { outside home } \\
\text { together } \\
\text { (5 activities) }\end{array}$ & $\begin{array}{c}\text { Activities } \\
\text { inside home } \\
\text { together } \\
\text { (3 activities) }\end{array}$ & $\begin{array}{l}\text { Child feels } \\
\text { close to } \\
\text { mother } \\
\text { (4 measures) }\end{array}$ & $\begin{array}{c}\text { Mother } \\
\text { knows child's } \\
\text { whereabouts } \\
\text { (1 measure) }\end{array}$ & $\begin{array}{l}\text { Composite } \\
\text { (all 13 } \\
\text { measures) }\end{array}$ \\
\hline $\begin{array}{l}\text { Any welfare } \\
\text { reform }\end{array}$ & $\begin{array}{c}0.02979 \\
(0.06324) \\
{[0.470]}\end{array}$ & $\begin{array}{c}-0.05890 \\
(0.09964) \\
{[0.554]}\end{array}$ & $\begin{array}{c}0.04561 \\
(0.07679) \\
{[0.553]}\end{array}$ & $\begin{array}{c}0.1743{ }^{\star} \\
(0.10353) \\
{[0.092]}\end{array}$ & $\begin{array}{l}0.02531 \\
(0.05227) \\
{[0.628]}\end{array}$ \\
\hline $\begin{array}{l}\text { Any welfare } \\
\text { reform * } \\
\text { target }\end{array}$ & $\begin{array}{c}-0.10438^{*} \\
(0.05839) \\
{[0.074]}\end{array}$ & $\begin{array}{c}0.00156 \\
(0.06960) \\
{[0.982]}\end{array}$ & $\begin{array}{c}-0.10005 \\
(0.06543) \\
{[0.126]}\end{array}$ & $\begin{array}{c}-0.09469 \\
(0.13938) \\
{[0.497]}\end{array}$ & $\begin{array}{c}-0.07786^{\star} \\
(0.04276) \\
{[0.069]}\end{array}$ \\
\hline $\mathrm{N}$ & 1876 & 1869 & 1678 & 1673 & 1999 \\
\hline
\end{tabular}

\begin{tabular}{|c|c|c|c|c|c|}
\hline & \multicolumn{5}{|c|}{ Girls 10-14 } \\
\hline & $\begin{array}{c}\text { Activities } \\
\text { outside home } \\
\text { together } \\
\text { (5 activities) }\end{array}$ & $\begin{array}{c}\text { Activities } \\
\text { inside home } \\
\text { together } \\
\text { (3 activities) }\end{array}$ & $\begin{array}{l}\text { Child feels } \\
\text { close to } \\
\text { mother } \\
\text { (4 measures) }\end{array}$ & $\begin{array}{c}\text { Mother } \\
\text { knows child's } \\
\text { whereabouts } \\
\text { (1 measure) }\end{array}$ & $\begin{array}{c}\text { Composite } \\
\text { (all } 13 \\
\text { measures) }\end{array}$ \\
\hline $\begin{array}{l}\text { Any welfare } \\
\text { reform }\end{array}$ & $\begin{array}{c}0.00468 \\
(0.06155) \\
{[0.939]}\end{array}$ & $\begin{array}{c}-0.19294^{\star *} \\
(0.08137) \\
{[0.018]}\end{array}$ & $\begin{array}{c}0.05580 \\
0.09312 \\
{[0.549]}\end{array}$ & $\begin{array}{r}0.29786 * \star \star \\
(0.11573) \\
{[0.010]}\end{array}$ & $\begin{array}{c}-0.00264 \\
(0.05168) \\
{[0.959]}\end{array}$ \\
\hline $\begin{array}{l}\text { Any welfare } \\
\text { reform * } \\
\text { target }\end{array}$ & $\begin{array}{c}0.03057 \\
(0.04844) \\
{[0.528]}\end{array}$ & $\begin{array}{c}-0.07128 \\
(0.08164) \\
{[0.383]}\end{array}$ & $\begin{array}{c}-0.03793 \\
(0.07724) \\
{[0.623]}\end{array}$ & $\begin{array}{c}-0.06196 \\
(0.10871) \\
{[0.569]}\end{array}$ & $\begin{array}{l}-0.02113 \\
(0.04499) \\
{[0.639]}\end{array}$ \\
\hline $\mathbf{N}$ & 1815 & 1811 & 1654 & 1670 & 1935 \\
\hline $\begin{array}{l}\text { Gender } \\
\text { Difference } \\
\text { [p-value] }\end{array}$ & [0.015] & [0.464] & [0.541] & [0.880] & {$[0.327]$} \\
\hline
\end{tabular}

Notes: Figures in each cell are OLS coefficient, standard error (in parentheses), and p-value [in brackets]. Estimates of interest are those of "Any Welfare Reform * Target," which are bolded. Standard errors are clustered at the statelevel. Asterisks denote significance as follows: ${ }^{* *} p$-value $\leq 0.01 ;{ }^{* *} 0.01<p$-value $\leq 0.05 ;{ }^{*} 0.05<p$-value $\leq 0.10$. All specifications include the following covariates: child's age, grade, and race/ethnicity; the mother's education and marital status; annual state-level measures (unemployment rate, poverty rate, personal income per capita, Earned Income Tax Credit (EITC) rate, refundable EITC, minimum wage, number Medicaid beneficiaries, numbers of National School Lunch and School Breakfast Program participants, and population); and indicators for state, year and month. Target group is children of single mothers with at most a high school education. Comparison group is children of single mothers with more than a high school education (Comparison Group B). 
Table 4: Seemingly Unrelated Regressions: Sensitivity of Estimated Effects of Welfare Reform to Alternate Specifications Comparison Group A

\begin{tabular}{|c|c|c|c|c|c|}
\hline & \multicolumn{5}{|c|}{ Boys 10-14 } \\
\hline & $\begin{array}{c}\text { Activities outside } \\
\text { home } \\
\text { together } \\
\text { (5 activities) }\end{array}$ & $\begin{array}{c}\text { Activities inside } \\
\text { home } \\
\text { together } \\
\text { (3 activities) }\end{array}$ & $\begin{array}{c}\text { Child feels close to } \\
\text { mother } \\
\text { (4 measures) }\end{array}$ & $\begin{array}{c}\text { Mother knows } \\
\text { child's whereabouts } \\
\text { (1 measure) }\end{array}$ & $\begin{array}{l}\text { Composite } \\
\text { (all } 13 \text { measures) }\end{array}$ \\
\hline Panel A & \multicolumn{5}{|c|}{$\begin{array}{c}\text { Basic Specification } \\
\text { Including Individual Covariates, State, Year, Month Fixed Effects }\end{array}$} \\
\hline $\begin{array}{l}\text { Any welfare } \\
\text { reform * target }\end{array}$ & $\begin{array}{c}-0.07743 \\
(0.04942) \\
{[0.117]}\end{array}$ & $\begin{array}{l}-0.06235 \\
(0.04002) \\
{[0.119]}\end{array}$ & $\begin{array}{l}-0.08176^{*} \\
(0.04439) \\
{[0.066]}\end{array}$ & $\begin{array}{l}-0.12360 \\
(0.07766) \\
{[0.112]}\end{array}$ & $\begin{array}{l}-\mathbf{0 . 0 7 8 8 3 * \star \star} \\
(0.03079) \\
{[0.010]}\end{array}$ \\
\hline Panel B & \multicolumn{5}{|c|}{ Basic Specification + State Covariates (Policies \& Economic Conditions) } \\
\hline $\begin{array}{l}\text { Any welfare } \\
\text { reform * target }\end{array}$ & $\begin{array}{c}-\mathbf{0 . 0 7 5 5 5} \\
(0.05003) \\
{[0.131]} \\
\end{array}$ & $\begin{array}{c}-0.06592 \\
(0.04017) \\
{[0.101]} \\
\end{array}$ & $\begin{array}{c}-0.09134^{* *} \\
(0.04519) \\
{[0.043]} \\
\end{array}$ & $\begin{array}{c}-0.14364^{*} \\
(0.07774) \\
{[0.065]} \\
\end{array}$ & $\begin{array}{c}-\mathbf{0 . 0 8 3 4 2 * * *} \\
(0.03149) \\
{[0.008]} \\
\end{array}$ \\
\hline Panel C & \multicolumn{5}{|c|}{$\begin{array}{c}\text { Extended Specification } \\
\text { Further Including Lagged Welfare Caseloads, Lagged Personal Income Per Capita, Lagged } \\
\text { Unemployment Rate, Lagged Poverty Rate }\end{array}$} \\
\hline $\begin{array}{l}\text { Any welfare } \\
\text { reform * target }\end{array}$ & $\begin{array}{l}-0.07999 \\
(0.04879) \\
{[0.101]}\end{array}$ & $\begin{array}{l}-0.06814^{*} \\
(0.03913) \\
{[0.082]}\end{array}$ & $\begin{array}{l}-0.09310^{* *} \\
(0.04589) \\
{[0.042]}\end{array}$ & $\begin{array}{c}-0.14497^{*} \\
(0.07727) \\
{[0.061]}\end{array}$ & $\begin{array}{c}\mathbf{- 0 . 0 8 6 2 9 * * *} \\
(0.03117) \\
{[0.006]}\end{array}$ \\
\hline $\mathrm{N}$ & 3761 & 3741 & 3350 & 3351 & 4002 \\
\hline
\end{tabular}


Table 4: Seemingly Unrelated Regressions: Sensitivity of Estimated Effects of Welfare Reform to Alternate Specifications Comparison Group A (continued)

\begin{tabular}{|c|c|c|c|c|c|}
\hline & \multicolumn{5}{|c|}{ Girls 10-14 } \\
\hline & $\begin{array}{c}\text { Activities outside } \\
\text { home } \\
\text { together } \\
\text { (5 activities) }\end{array}$ & $\begin{array}{c}\text { Activities inside } \\
\text { home } \\
\text { together } \\
\text { (3 activities) }\end{array}$ & $\begin{array}{c}\text { Child feels close to } \\
\text { mother } \\
\text { (4 measures) }\end{array}$ & $\begin{array}{c}\text { Mother knows } \\
\text { child's whereabouts } \\
\text { (1 measure) }\end{array}$ & $\begin{array}{l}\text { Composite } \\
\text { (all } 13 \text { measures) }\end{array}$ \\
\hline Panel A & \multicolumn{5}{|c|}{$\begin{array}{c}\text { Basic Specification } \\
\text { Including Individual Covariates, State, Year, Month Fixed Effects }\end{array}$} \\
\hline $\begin{array}{l}\text { Any welfare } \\
\text { reform * target }\end{array}$ & $\begin{array}{c}\mathbf{0 . 0 0 7 2 2} \\
(0.04155) \\
{[0.862]}\end{array}$ & $\begin{array}{l}-0.08336^{*} \\
(0.04733) \\
{[0.078]}\end{array}$ & $\begin{array}{c}-\mathbf{0 . 0 2 9 5 1} \\
(0.06749) \\
{[0.662]}\end{array}$ & $\begin{array}{c}-0.00228 \\
(0.07197) \\
{[0.975]}\end{array}$ & $\begin{array}{l}-\mathbf{0 . 0 2 5 7 2} \\
(0.03557) \\
{[0.470]}\end{array}$ \\
\hline Panel B & \multicolumn{5}{|c|}{ Basic Specification + State Covariates (Policies \& Economic Conditions) } \\
\hline $\begin{array}{l}\text { Any welfare } \\
\text { reform * target }\end{array}$ & $\begin{array}{c}\mathbf{0 . 0 0 8 6 0} \\
(0.04158) \\
{[0.836]} \\
\end{array}$ & $\begin{array}{c}-0.08251^{*} \\
(0.04698) \\
{[0.079]} \\
\end{array}$ & $\begin{array}{c}-\mathbf{0 . 0 3 3 9 6} \\
(0.06814) \\
{[0.618]} \\
\end{array}$ & $\begin{array}{c}\mathbf{0 . 0 0 3 3 1} \\
(0.07264) \\
{[0.964]} \\
\end{array}$ & $\begin{array}{c}-\mathbf{0 . 0 2 5 9 3} \\
(0.03532) \\
{[0.463]} \\
\end{array}$ \\
\hline Panel C & \multicolumn{5}{|c|}{$\begin{array}{c}\text { Extended Specification } \\
\text { Further Including Lagged Welfare Caseloads, Lagged Personal Income Per Capita, Lagged } \\
\text { Unemployment Rate, Lagged Poverty Rate }\end{array}$} \\
\hline $\begin{array}{l}\text { Any welfare } \\
\text { reform * target }\end{array}$ & $\begin{array}{c}\mathbf{0 . 0 0 8 2 1} \\
(0.04236) \\
{[0.846]}\end{array}$ & $\begin{array}{c}-0.08324^{*} \\
(0.04739) \\
{[0.079]}\end{array}$ & $\begin{array}{c}-\mathbf{0 . 0 3 4 1 3} \\
(0.06891) \\
{[0.620]}\end{array}$ & $\begin{array}{c}\mathbf{0 . 0 0 8 0 2} \\
(0.07288) \\
{[0.912]}\end{array}$ & $\begin{array}{c}\mathbf{- 0 . 0 2 5 9 3} \\
(0.03618) \\
{[0.473]}\end{array}$ \\
\hline $\mathrm{N}$ & 3639 & 3637 & 3243 & 3245 & 3843 \\
\hline
\end{tabular}

Notes: Figures in each cell are OLS coefficient, standard error (in parentheses), and p-value [in brackets]. Estimates of interest are those of "Any Welfare Reform *

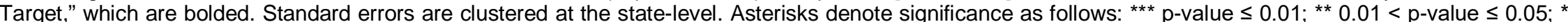
$0.05<p$-value $\leq 0.10$. All specifications include the following covariates: child's age, grade, and race/ethnicity; the mother's education and marital status, and indicators for state, year, and month. State-level covariates include: unemployment rate, poverty rate, personal income per capita, Earned Income Tax Credit (EITC) rate, refundable EITC, minimum wage, number Medicaid beneficiaries, numbers of National School Lunch and School Breakfast Program participants, and population. Extended specification (same as in Table 2) further includes one-year, two-year, and three-year lags of the state unemployment rate, state personal income per capita, state poverty rate, and state welfare caseloads. Target group is children of single mothers with at most a high school education. Comparison group is children of married mothers with at most a high school education (Comparison Group A). 
Table 5: Seemingly Unrelated Regressions: Estimated Effects of Welfare Reform on Parenting Outcomes - Testing Lead Policy Effects

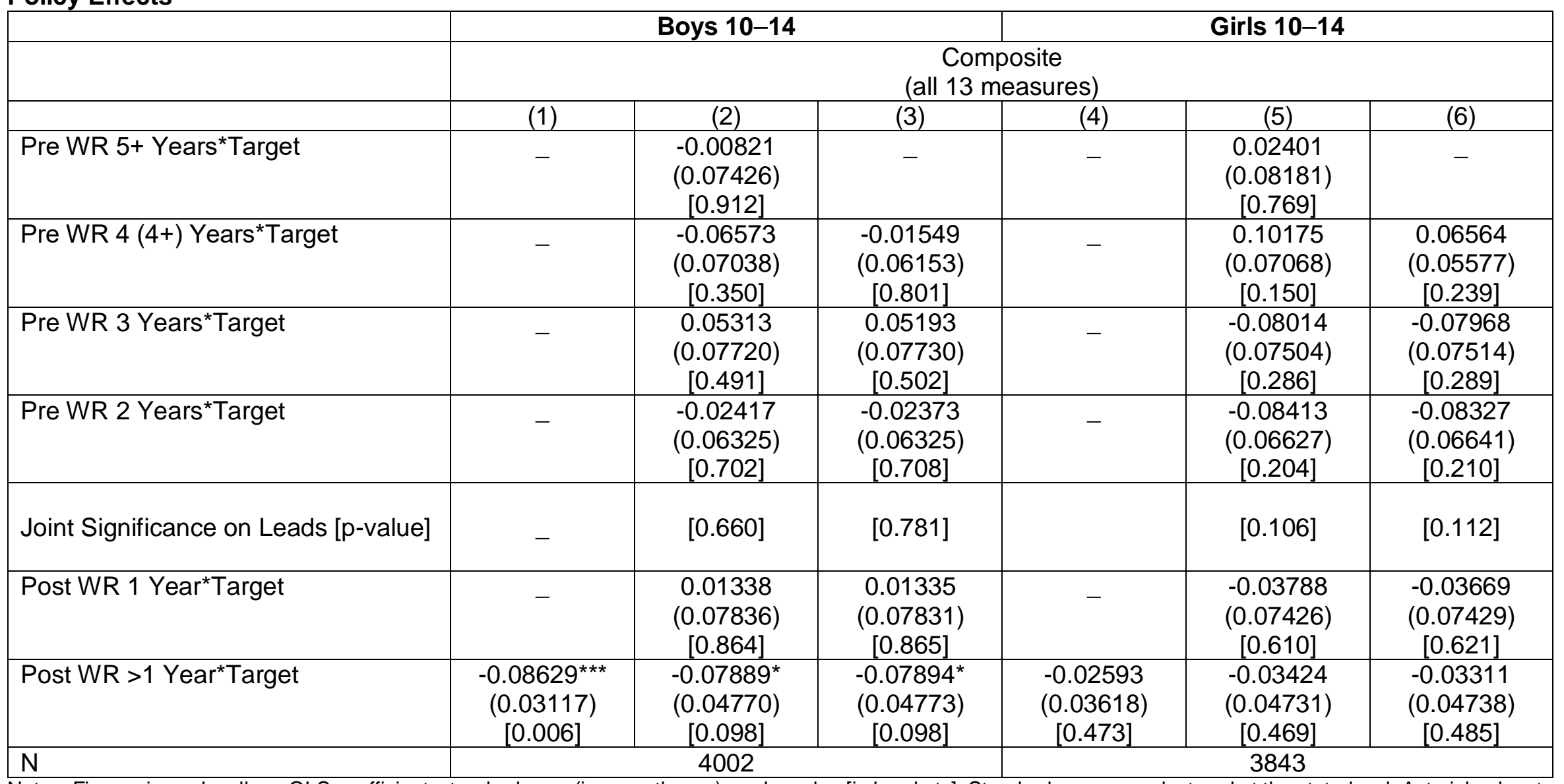

Notes: Figures in each cell are OLS coefficient, standard error (in parentheses), and p-value [in brackets]. Standard errors are clustered at the state-level. Asterisks denote significance as follows: *** p-value $\leq 0.01 ;{ }^{* *} 0.01<\mathrm{p}$-value $\leq 0.05 ;{ }^{*} 0.05<\mathrm{p}$-value $\leq 0.10$. Models are jointly estimated using a seemingly unrelated regression (SUR) framework. All outcomes are redefined as standard normal deviates (see text). Each column in each panel presents estimates from a separate model. All specifications include the following covariates: child's age, grade, and race/ethnicity; the mother's education and marital status; annual state-level measures (unemployment rate, poverty rate, personal income per capita, Earned Income Tax Credit (EITC) rate, refundable EITC, minimum wage, number Medicaid beneficiaries, numbers of National School Lunch and School Breakfast Program participants, and population); and indicators for state, year and month. Target group is children of single mothers with at most a high school education. Comparison group is children of married mothers with at most a high school education (Comparison Group A). 
Table 6: Seemingly Unrelated Regressions: Estimated Effects of Welfare Reform on Parenting Outcomes - High Educated Married Mothers

\begin{tabular}{|l|c|c|c|c|c|}
\hline & \multicolumn{5}{|c|}{ Boys 10-14 } \\
\hline & $\begin{array}{c}\text { Activities } \\
\text { outside home } \\
\text { together } \\
\text { (5 activities) }\end{array}$ & $\begin{array}{c}\text { Activities } \\
\text { inside home } \\
\text { together } \\
(3 \text { activities })\end{array}$ & $\begin{array}{c}\text { Child feels } \\
\text { close to } \\
\text { mother } \\
\text { (4 measures) }\end{array}$ & $\begin{array}{c}\text { Mother knows } \\
\text { child's } \\
\text { whereabouts } \\
(1 \text { measure) }\end{array}$ & $\begin{array}{c}\text { Composite } \\
\text { (all 13 } \\
\text { measures) }\end{array}$ \\
\hline Any & -0.04374 & -0.01338 & -0.03490 & 0.00626 & -0.03017 \\
welfare & $(0.07386)$ & $(0.08408)$ & $(0.05606)$ & $(0.13767)$ & $(0.04599)$ \\
reform & {$[0.554]$} & {$[0.874]$} & {$[0.534]$} & {$[0.964]$} & {$[0.512]$} \\
\hline $\mathrm{N}$ & 1674 & 1663 & 1635 & 1646 & 1836 \\
\hline
\end{tabular}

\begin{tabular}{|l|c|c|c|c|c|}
\hline & \multicolumn{5}{|c|}{ Girls 10-14 } \\
& $\begin{array}{c}\text { Activities } \\
\text { outside home } \\
\text { together } \\
\text { (5 activities) }\end{array}$ & $\begin{array}{c}\text { Activities } \\
\text { inside home } \\
\text { together } \\
(3 \text { activities })\end{array}$ & $\begin{array}{c}\text { Child feels } \\
\text { close to } \\
\text { mother } \\
(4 \text { measures })\end{array}$ & $\begin{array}{c}\text { Mother knows } \\
\text { child's } \\
\text { whereabouts } \\
(1 \text { measure) }\end{array}$ & $\begin{array}{c}\text { Composite } \\
\text { (all 13 } \\
\text { measures) }\end{array}$ \\
\hline Any & -0.06962 & -0.05861 & -0.01309 & -0.07816 & -0.05034 \\
welfare & 0.05835 & $(0.06174)$ & 0.06593 & $(0.11426)$ & $(0.03590)$ \\
reform & {$[0.233]$} & {$[0.343]$} & {$[0.843]$} & {$[0.494]$} & {$[0.161]$} \\
\hline $\mathrm{N}$ & 1715 & 1704 & 1668 & 1664 & 1852 \\
\hline
\end{tabular}

Notes: Figures in each cell are OLS coefficient, standard error (in parentheses), and p-value [in brackets]. Standard errors are clustered at the state-level. Asterisks denote significance as follows: ${ }^{\star \star *} p$-value $\leq 0.01 ;{ }^{* *} 0.01<p$-value $\leq$ $0.05 ;{ }^{*} 0.05<p$-value $\leq 0.10$. All specifications include the following covariates: child's age, grade, and race/ethnicity; the mother's education and marital status; annual state-level measures (unemployment rate, poverty rate, personal income per capita, Earned Income Tax Credit (EITC) rate, refundable EITC, minimum wage, number Medicaid beneficiaries, numbers of National School Lunch and School Breakfast Program participants, and population); and indicators for state, year and month. Sample is restricted to married mothers with some college education or above. 
Appendix Table 1: Estimated effects of welfare reform on activities outside home with parent(s) (past month) - Comparison Group A

\begin{tabular}{|c|c|c|c|c|c|}
\hline & \multicolumn{5}{|c|}{ Boys } \\
\hline & Movies & Dinner & $\begin{array}{l}\text { Shopping for } \\
\text { child }\end{array}$ & Outings & Church \\
\hline \multirow{2}{*}{$\begin{array}{l}\text { Any welfare } \\
\text { Reform }\end{array}$} & -0.00554 & -0.06072 & $0.05968^{\star \star}$ & -0.00949 & -0.03589 \\
\hline & $(0.04208)$ & $(0.03764)$ & $(0.02417)$ & $(0.03459)$ & $(0.04180)$ \\
\hline \multirow{2}{*}{$\begin{array}{l}\text { Any welfare } \\
\text { reform * target }\end{array}$} & $-0.09465^{\star}$ & -0.04251 & -0.02795 & -0.05195 & 0.03068 \\
\hline & $(0.04712)$ & $(0.03448)$ & $(0.03087)$ & $(0.03308)$ & $(0.04223)$ \\
\hline Observations & 3705 & 3714 & 3737 & 3704 & 3698 \\
\hline
\end{tabular}

\begin{tabular}{|c|c|c|c|c|c|}
\hline & \multicolumn{5}{|c|}{ Girls } \\
\hline & Movies & Dinner & $\begin{array}{l}\text { Shopping for } \\
\text { child }\end{array}$ & Outings & Church \\
\hline \multirow{2}{*}{$\begin{array}{l}\text { Any welfare } \\
\text { reform }\end{array}$} & -0.00371 & 0.00736 & $-0.05391^{\star *}$ & 0.05297 & 0.03542 \\
\hline & $(0.03739)$ & $(0.03255)$ & $(0.02552)$ & $(0.03782)$ & $(0.04596)$ \\
\hline \multirow{2}{*}{$\begin{array}{l}\text { Any welfare } \\
\text { reform * target }\end{array}$} & 0.05240 & -0.00706 & 0.00733 & -0.02727 & -0.00793 \\
\hline & $(0.04415)$ & $(0.04891)$ & $(0.02146)$ & $(0.02782)$ & $(0.03990)$ \\
\hline Observations & 3593 & 3601 & 3619 & 3589 & 3585 \\
\hline
\end{tabular}

Notes: Figures in each cell are OLS coefficient, standard error (in parentheses), and p-value [in brackets]. Estimates of interest are those of "Any Welfare Reform * Target," which are bolded. Standard errors are clustered at the statelevel. Asterisks denote significance as follows: ${ }^{* *} p$-value $\leq 0.01 ;{ }^{* *} 0.01<p$-value $\leq 0.05 ;{ }^{*} 0.05<p$-value $\leq 0.10$. All specifications include the following covariates: child's age, grade, and race/ethnicity; the mother's education and marital status; annual state-level measures (unemployment rate, poverty rate, personal income per capita, Earned Income Tax Credit (EITC) rate, refundable EITC, minimum wage, number Medicaid beneficiaries, numbers of National School Lunch and School Breakfast Program participants, and population); and indicators for state, year and month. Target group is children of single mothers with at most a high school education. Comparison group is children of married mothers with at most a high school education (Comparison Group A). 
Appendix Table 2: Estimated effects of welfare reform on activities in home with parents (past week) and mother knows child's whereabouts - Comparison Group A

\begin{tabular}{|c|c|c|c|c|}
\hline & \multicolumn{4}{|c|}{ Boys } \\
\hline & $\begin{array}{l}\text { Schoolwork } \\
\text { together }\end{array}$ & $\begin{array}{l}\text { Played } \\
\text { together }\end{array}$ & $\begin{array}{c}\text { Other activities } \\
\text { together }\end{array}$ & $\begin{array}{l}\text { Mom often knows } \\
\text { child's whereabouts }\end{array}$ \\
\hline \multirow{2}{*}{$\begin{array}{l}\text { Any welfare } \\
\text { reform }\end{array}$} & -0.02583 & 0.02699 & -0.00485 & 0.01369 \\
\hline & $(0.04287)$ & $(0.03895)$ & $(0.03599)$ & $(0.02703)$ \\
\hline \multirow{2}{*}{$\begin{array}{l}\text { Any welfare } \\
\text { reform * target }\end{array}$} & -0.01520 & -0.00545 & $-0.08094^{* * *}$ & $-0.06315^{*}$ \\
\hline & $(0.03197)$ & $(0.03207)$ & $(0.02683)$ & $(0.03433)$ \\
\hline \multirow[t]{3}{*}{ Observations } & 3702 & 3702 & 3700 & 3351 \\
\hline & \multicolumn{4}{|c|}{ Girls } \\
\hline & $\begin{array}{l}\text { Schoolwork } \\
\text { together }\end{array}$ & $\begin{array}{l}\text { Played } \\
\text { together }\end{array}$ & $\begin{array}{c}\text { Other activities } \\
\text { together }\end{array}$ & $\begin{array}{l}\text { Mom often knows } \\
\text { child's whereabouts }\end{array}$ \\
\hline \multirow{2}{*}{$\begin{array}{l}\text { Any welfare } \\
\text { reform }\end{array}$} & -0.03710 & 0.00217 & $-0.06305^{\star \star}$ & 0.02718 \\
\hline & (0.03539) & $(0.04321)$ & $(0.02451)$ & $(0.02564)$ \\
\hline \multirow{2}{*}{$\begin{array}{l}\text { Any welfare } \\
\text { reform * target }\end{array}$} & -0.03806 & $-0.07609 * *$ & -0.00809 & 0.00295 \\
\hline & $(0.02947)$ & $(0.03451)$ & $(0.03176)$ & $(0.02733)$ \\
\hline Observations & 3600 & 3593 & 3616 & 3245 \\
\hline
\end{tabular}

Notes: Figures in each cell are OLS coefficient, standard error (in parentheses), and p-value [in brackets]. Estimates of interest are those of "Any Welfare Reform * Target," which are bolded. Standard errors are clustered at the statelevel. Asterisks denote significance as follows: *** $p$-value $\leq 0.01 ;{ }^{* *} 0.01<p$-value $\leq 0.05 ;{ }^{*} 0.05<p$-value $\leq 0.10$. All specifications include the following covariates: child's age, grade, and race/ethnicity; the mother's education and marital status; annual state-level measures (unemployment rate, poverty rate, personal income per capita, Earned Income Tax Credit (EITC) rate, refundable EITC, minimum wage, number Medicaid beneficiaries, numbers of National School Lunch and School Breakfast Program participants, and population); and indicators for state, year and month. Target group is children of single mothers with at most a high school education. Comparison group is children of married mothers with at most a high school education (Comparison Group A). 
Appendix Table 3: Close to Mother - Comparison Group A

\begin{tabular}{|l|c|c|c|c|}
\hline & \multicolumn{4}{|c|}{ Boys } \\
\hline & $\begin{array}{c}\text { Mother spends } \\
\text { enough time (or } \\
\text { more) with child }\end{array}$ & $\begin{array}{c}\text { Mother/child } \\
\text { share ideas } \\
\text { quite or } \\
\text { extremely well }\end{array}$ & $\begin{array}{c}\text { Mother almost } \\
\text { never misses } \\
\text { child's important } \\
\text { events }\end{array}$ & $\begin{array}{c}\text { Child feel quite } \\
\text { or extremely } \\
\text { close to mother }\end{array}$ \\
\hline $\begin{array}{l}\text { Any welfare } \\
\text { reform }\end{array}$ & 0.03834 & 0.00274 & 0.04820 & -0.00855 \\
\hline $\begin{array}{l}\text { Any welfare } \\
\text { reform * Target }\end{array}$ & $\mathbf{( 0 . 0 2 2 9 0 )}$ & $(0.03020)$ & $(0.04457)$ & $(0.01587)$ \\
\cline { 2 - 5 } & $\mathbf{- 0 . 0 4 2 3 2}$ & $\mathbf{- 0 . 0 5 8 5 8 * *}$ & $-\mathbf{0 . 0 1 0 4 2}$ & $\mathbf{- 0 . 0 2 9 3 6}$ \\
\hline Observations & 3181 & $\mathbf{( 0 . 0 2 6 1 8 )}$ & $\mathbf{( 0 . 0 3 9 7 8 )}$ & $\mathbf{( 0 . 0 2 3 4 3 )}$ \\
\hline
\end{tabular}

\begin{tabular}{|l|c|c|c|c|}
\hline & \multicolumn{4}{|c|}{ Girls } \\
\hline & $\begin{array}{l}\text { Mother spends } \\
\text { enough time (or } \\
\text { more) with child }\end{array}$ & $\begin{array}{c}\text { Mother/child } \\
\text { share ideas } \\
\text { quite or } \\
\text { extremely well }\end{array}$ & $\begin{array}{c}\text { Mother almost } \\
\text { never misses } \\
\text { child's important } \\
\text { events }\end{array}$ & $\begin{array}{c}\text { Child feel quite } \\
\text { or extremely } \\
\text { close to mother }\end{array}$ \\
\hline $\begin{array}{l}\text { Any welfare } \\
\text { reform }\end{array}$ & $0.11669 * \star *$ & 0.00278 & 0.03374 & 0.01520 \\
\hline $\begin{array}{l}\text { Any welfare } \\
\text { reform * target }\end{array}$ & $\mathbf{0 . 0 2 9 4 7 )}$ & $(0.04389)$ & $(0.03888)$ & $(0.02528)$ \\
\hline Observations & $\mathbf{( 0 . 0 5 0 6 3 )}$ & $\mathbf{0 . 0 0 1 8 9}$ & $\mathbf{0 . 0 1 6 7 0}$ & $\mathbf{- 0 . 0 2 9 7 7}$ \\
\hline
\end{tabular}

Notes: Figures in each cell are OLS coefficient, standard error (in parentheses), and p-value [in brackets]. Estimates of interest are those of "Any Welfare Reform * Target," which are bolded. Standard errors are clustered at the statelevel. Asterisks denote significance as follows: ${ }^{* \star \star} p$-value $\leq 0.01 ;{ }^{* \star} 0.01<p$-value $\leq 0.05 ;{ }^{*} 0.05<p$-value $\leq 0.10$. All specifications include the following covariates: child's age, grade, and race/ethnicity; the mother's education and marital status; annual state-level measures (unemployment rate, poverty rate, personal income per capita, Earned Income Tax Credit (EITC) rate, refundable EITC, minimum wage, number Medicaid beneficiaries, numbers of National School Lunch and School Breakfast Program participants, and population); and indicators for state, year and month. Target group is children of single mothers with at most a high school education. Comparison group is children of married mothers with at most a high school education (Comparison Group A). 